\title{
CONTEMPORARY ISLAMIC THOUGHT PARADIGM IN UNDERSTANDING TURÂTH AND MODERNITY
}

\author{
Abdul Mukti Ro'uf \\ Institut Agama Islam Negeri Pontianak, Indonesia \\ muktirouf@yahoo.com \\ Article history: \\ Submitted: 20-03-2018 | Revised: 07-08-2018 | Accepted: 14-11-2018
}

\begin{abstract}
This article describes the current map of contemporary Islamic thought in term of understanding the relation between legacy (turâth) and modernity within the context of Arab-Islamic renaissance. Some paradigms of thoughts raised by various critical Arab thinkers converge into one general goal: reviving Arab-Islam civilization from its long hibernation. The theme of "self-criticism" (an-naqd al-dhâtiy) has become a core issue that dominates the discourse of contemporary Islamic thoughts and encompasses other paradigms such as Marxism, liberalism, fundamentalism, nasionalism and post-traditionalism. Although they have a common goal, they have distinctive methods in reading and treating the relation between legacy and modern.
\end{abstract}

Keywords: Turâth, modernity, self-criticism

\begin{abstract}
Abstrak
Artikel ini hendak menggambarkan peta pemikiran Islam kontemporer dalam memahami warisan pemikiran (turâth) dan modernitas dalam kerangka upaya kebangkitan Arab-Islam. Paradigma pemikiran yang ditawarkan berbagai kelompok umumnya bermuara kepada satu tujuan, yaituupaya membangkitkan peradaban Arab-Islam dari tidur panjangnya. Tema "kritik diri" (al-Naqd al-Dhâtî) menjadi diskursus yang mendominasi pemikiran Islam kontemporer sejak tahun 1967. Paradigma pemikiran Marxisme, Liberalisme, Fundamentalisme, Nasionalisme, dan post-tradisionalisme, meskipun memiliki tujuan yang sama, namun memiliki metode yang berbeda-beda dalam membaca dan memperlakukan warisan pemikiran dan modernitas.
\end{abstract}

Kata Kunci: Turâth, modernitas, kritik diri.

\section{Introduction}

In general, this study reflects the intellectual unease of Arab-Islamic thinkers over setbacks in many fields, especially in the field of science and technology, especially after the defeat of the
Arabs by Israel in $1967 .{ }^{1}$ At the same time, the

'For further details, read the works of Ibrahim Abu Rabi', Including Contemporary Arab Thought: Studies in Post1967 Arab Intellectual History (London: Pluto Press, 2004), 43-45; " "Contemporary Islamic Intellectual History: 
Arab-Islamic civilization faced with the reality about the progress of Western civilization with its modernization project. The discourse of modernity itself, as the achievement of Western civilization with all its advantages and disadvantages, becomes problematic when entering the territory of Arab-Islamic civilization. Acceptance and rejection of modernism is unavoidable in Islamic thought. The pros and cons over this issue lead to a discourse on "self-criticism" by proposing the basic issue, whether turâth is taken in for the interest of modernity or vice versa. In this study, the stream of contemporary Islamic thought results in many variants, models and approaches.

With this basic issue, this study proposes three hypotheses. First, the problem of the Arab-Islamic revival cannot escape the Arab-Islamic legacy (turâth) which goes far back to the past. Second, turâth - referring to the definition by Muhammad 'Âbid al-Jâbirî - is "an intellectual heritage both old and new or positive and negative heritage and accompanying our present". It has shaped the way of thinking and behaving towards the today's realities. Third, legacy and modernity (al-Turâth wa al-Hadâtah) in the context of awakening (nahdah) is not a contradictive relationship, but a dialogic-dialectic relationship. From these three hypotheses, various thoughts of experts are mapped out through a contemporary Islamic thought paradigm. This study focuses more on mapping out the paradigm to answer three fundamental issues. As a conceptual-theoretical endeavor, it becomes an entry point for social movements for

A Theoretical Perspective, "Islamic Studies 44, no. 4 (2005): 503-526. http://www.jstor.org/stable/20838990. (accessed on July 23, 2014); "Islamic Resurgence and The Problematic of Tradition in The Modern Arab World: The Contemporary Academic Debate," Islamic Studies 34, no. 1 (1995): 43-66. http://www.jstor.org/stable/20840194. (accessed on June 16, 2014). Compare with Israel Gershoni, "Trends and Issues in Contemporary Arab Thought by Issa J. Boullata," Middle Eastern Studies 28, no. 3 (1992): 609-616. http://www.jstor.org/ stable/4283517. (accessed on June 16, 2014); Yudian Wahyudi, The Slogan "Back ti The Qur'ân and Sunna: A Comparative Study of The Responses of Hasan Hanafi, Muhammad 'Âbid alJâbirî, and Nurholish Madjid, Disertation (Canada: The Institute of Islamic Studies McGill University Montreal, 2012), 120. one purpose: to catch up with the modern-Western civilization by the Arab-Islamic civilization.

\section{Contemporary Islamic Thought Paradigm}

Experts map out contemporary views of Islamic thought on tradition and modernity especially after the defeat of Arab in 1967 into several groups. Issa J. Boullata, for example, divides them into three groups. First, the group that offers transformative discourse, expecting the Arab world to be completely separated from its past traditions because they are no longer adequate for contemporary life. These figures are generally Marxists such as Salamah Mūsa (1887-1958), Zakī Najīb Mahmūd (1905-1993), and Adonis (b. 1930). Second, groups that offer reformative discourse, expecting an accommodative attitude by reforming the traditions they have been facing. The representatives of this group include Mohammad Arkoun (1928-2010), Hassan Hanafi (b. 1935), and Muhammad 'Âbid al-Jâbirî (1935-2010). Third, the group called idealistictotalistic, expecting the Arab world to return to the pure Islam, especially the conservative school with its slogan "back to the Qur'an and hadith". This group is represented by Muhammad Ghazali (1917-1996), Sayyid Qutb (1906-1966), andMuhammad Qutb (1919-2014). ${ }^{2}$

Besides the study of Boullata, the studies conducted by Abdullah Bulqaziz ${ }^{3}$, Fouad Ajami ${ }^{4}$, and Cheryl Benard ${ }^{5}$ offer similar discourse and mapping analysis. Bulqaziz, for instance, divides them into four groups; Marxist Arabs, Arab Nationalists, Liberal Intellectuals, and Fundamentalists. In the meantime, Ajami classifies

\footnotetext{
${ }^{2}$ Issa J. Boullata, Trends and Issues in Contemporery Arab Thougt (New York: State University of New York Press, 1990), 17-22.

${ }^{3}$ Abdullah Bulqaziz, "Wahid wa 'Ishrun 'ala Hazimah Haziran: al-Asbab, al-Hasilah, al-Afaq”, al-Mustaqbal al-Arabi, no. 112 (1998).

${ }^{4}$ Fouad Ajami, Arab Predicament: Arab Poloitical Thought and Practice Since 1967 (Cambridge: Cambridge University Press, 1981), 38-59.

${ }^{5}$ Cheryl Benard, Civil Democratic Islam; Partners, Resources and Strategies (Rand Corporation Santa Monica: CA, 2003), 2533.
} 
them into; Neo Radical Criticism Movement, Self-Defense Movement from the Ruling Party (Ba'th Party), Radical Islamic Fundamentalism, and Conservative Fundamentalism.

Some of the works produced after the defeat (defitism, Hazimah) of Arab in 1967 which is considered as a crisis in the Arab world generally lead to self criticism to place turāth in a favorable position to the Arab-Islamic revival. ${ }^{6}$ Abdullah Laroui's opinion strengthens this idea. He argues the crisis has become a psychological problem for Arabs against contemporary phenomena which force them to revisit their traditions. ${ }^{7}$

Many arguments and analysis on some of these works classify contemporary Arabic thought into several discourses, ones of which are; first, the discourse on the impact of the 1967's defitism on Arab social and intellectual life; second, socialeconomic discourse after "the Oil Boom", and third, the discourse on the influence of Western Post-liberal thinking on Arab society. ${ }^{9}$

Amin Abdullah classifies two trends of Islamic thoughts in understanding turāth, first, those who underline the need to preserve the Islamic turāth that has been built firmly since centuries ago and use it to filter and repress the negative aspects of the development and modernization movement in all fields. Second,

\footnotetext{
${ }^{6}$ One example of discussions regarding various thoughts about self-criticism of Arabs after the 1967 is seen in Roger Louis dan Avi Shlaim, Ed. The 1967 Arab-Israel War: Origin and Consequence (Cambridge: Cambridge University Press, 2012), $1-21$.

${ }^{7}$ Abdullah Laroui, The Crisis of The Arab Intellectual: Traditionlism or Historicism? Trans. Diarmid Camell (Berkeley: University California Press, 1976), 1-15.

${ }^{8}$ The oil boom here is the oil crisis that occurred in 1973-1874 which was motivated by the Arab-Israeli conflict since the defeat of Arab by Israel in the 1967 war. The Arab-Israeli war in 1973 for twenty days is known as the fourth war. Here, the Arab world used oil as a 'political weapon' by raising prices and reducing production. The aim was to suppress Israeli supporters, especially the United States. See, Feby Dasa Eka Putri, "Oil Crisis of 1973-1974 in Industrial Countries as a New World Economic Governance Driver", AVATARA, Journal of Educational History 2, no. 1 (2014): 42-57.

${ }^{9}$ Eiji Nagasawa, "An Introductory Note on Contemporary Arabic Thought”, Civilisations 15, no. 1 (1965), 45-72 http:/hdl.handle. net/100086/14819 (accessed on September 5, 2014).
}

those who view the turāth critically. ${ }^{10}$ The first perspective understands the turāth as something which is rigid, final, and irreversible, whereas the second point of view sees the turäth as an ordinary "historical product" which indeed - copying the term by Amin Abdullah - qabil li al-Taghyir wa qabil li al-Niqas.

Further, the second group views turäth as something which is alive, developed, continuously measured, assessed, lived, and discovered, not something which is rigid, final, and irreversible. Therefore, the interpretation process will always be open. What Gadamer says as "fusion of horizons" is not something that is once and final, but more like a moving horizon. The understanding process, he adds, is basically a "historical effect event". ${ }^{11}$ Hamid Abu Zayd, an Egyptian thinker, uses the term there is always jadaliyyat al-alaqah bain al-Nass wa al-waqi' (dialectical relationship between reality and text). ${ }^{12}$

In fact, if examined more deeply, the rigidity of this tradition is, on the one hand, the invention of the modern world and reaction to the claim of modernity, on the other. The point is - referring to the spirit of modernism - the modern world is born from the passion to set aside the tradition and pledge human autonomy. That is the Cartesian passion, in which Descartes underwent his most radical methodical doubts and discarding all inherited certainty to reach the absolute statement of "Cogito, ergo sum". Similarly, Kantian formulated the whole spirit of Aufklarung as a manifestation of "Sapere Aude!"13 only by daring

\footnotetext{
${ }^{10}$ Amin Abdullah, Islamic Studies di Perguruan Tinggi: Pendekatan Integratif-Interkonektif (Yogyakarta: Pustaka Pelajar, 2006), 293-304.

${ }^{11}$ Hans-Georg Gadamer, 293. Also see, Trisno S. Sutanto, "Historisitas Pemahaman", Majalah Filsafat Diryakara XXV, no.2, 21-38.

${ }^{12}$ Nasr Hamid Abu Zayd, al-Nass, al-Sultah, al-Haqiqah: alFikr al-Dini, Bain Iradah al-Ma'rifah wa Iradah al-Haiminah (Beirut: Markaz al-Thaqafial-'Arabi, 1994), 74.

${ }^{13}$ The term Sapere Aude comes from Latin. Sapere (thinking, understanding) and Aude (dare). So the word Sapere Aude is interpreted as daring to think. This concept stems from the enlightenment of Immanuel Kant who said that enlightenment is human liberation from the immaturity they've made themselves. Immaturity is the inability to use their own understanding without
} 
to think for himself. According to him, one can come out of his/her "immaturity" in terms of dependence and submission to other authorities beyond the ability of human reasonability itself such as scriptures, institutions, figures or anything inherited in the name of "tradition". ${ }^{14}$

Various basic assumptions, both developed by those who want the constancy of turāth and those who take action to criticize it, are actually showing tension in negotiating moral ideals (maqāshid al-shari'ah) which are meta- historical and a changing socio-historical context.

To explore more details regarding the two perspectives above, especially from the perspective of contemporary Islamic thinkers post 1967 - referring to the categorization of Issa J. Boullata - the problem of turāth is seen form three approaches; idealistic, totalistic, transformative, and reformative approaches. ${ }^{15}$ These three models, although often overlapping mainly in including a thinker in a particular category, places the problem of reading or epistemological criticism as their core idea.

\section{a. Ideal Totalistic Approach}

This approach is often paired with a fundamentalist approach, ${ }^{16}$ a term which is

the guidance of others. It happened without a cause. It is not even a lack of mind but a lack of firmness and courage to use the mind without the guidance of others. Sapere Aude! Dare to use your own mind! Dare to know! That is the motto of enlightenment". See Immanuel Kant, What is Enlightenment? Translated and edited by LW. Beck (Indianapdis: Bobbs-Merrill, 1959), 85.

${ }^{14}$ Trisno S. Sutanto, "Islam Sebagai "Proyek": Catatan Pinggir Untuk Ulil", Essay, cited from https://www.academia. edu/7854184/ (accessed on January 10, 2016).

${ }^{15}$ It must be admitted that the categorization made by Issa J. Boullata or other scholars does not fully have clear-cut boundaries, but in general, it can at least be explained through one of these categorizations.

${ }^{16}$ The term "fundamentalism" first appeared in The Shorter English Dictionary in 1923, after twelve theological treatises entitled The Fundamentals: A Testimony to Truth were published. The writing, by the translators, was reported using Scientific Critical Approach by Protestant experts on the study of the Gospel. Thus, the term fundamentalism has arisen from outside the historical tradition of Islam, and was originally a religious movement among Protestants in the United States in the 1920s. Given this origin, it is said the fundamentalism is actually very typical of Christianity. However, apart from its Protestant background, the term fundamentalism is often used always debatable in its meaning that refers to groups who expect the return of the past glory and it is totally connected to the present. Those who reject the invitation of modernists include Jamaluddin al-Afghani and Muhammad Abduh. Al-Jābirī defines the fundamentalist movement as a movement that brings the flag of authenticity (al-As'a), interwoven with the roots of tradition as a mechanism to maintain certain individual identities based on Islamic values themselves, the 'pure Islam' and not Islam as practiced by the today's Muslims. ${ }^{17}$

Apart from the debate about the meaning of fundamentalism in Islam and the inherent positive and negative aspects in the context of its response to turäth, it is generally agreed that it - as long as it thinks about religion - has a general view that "basic teaching", "the original teaching" is the right one. Suchoriginal teaching can only be found in literal texts. ${ }^{18}$

The main characteristic of this typology is the idealistic attitude and view of totalistic Islamic teachings. This group sticks to the religious aspects of Islamic culture. The civilization project they are willing to work on is to revive Islam as a religion, culture and civilization. They reject foreign elements that come from the West as Islam itself is sufficient and adequate, covering social, political and economic regulations. ${ }^{19}$

to refer to religious phenomena that have similarities with the basic character of Protestant fundamentalism. No wonder if phenomena of thoughts, movements and fundamentalist groups in all religions, such as Islamic fundamentalism, Judaism, Hinduism and Buddhism are found. See, William Shepard, "Fundamentalism of Christian and Islamic," Religion, 17 (1987): 355-378. Compare this with, William Shepard, "What is Islamic Fundamentalism?" Studies in Religion 17, no. 1 (1988): 5-25. In Islam, fundamentalism is usually equated with al-Usuliyyah alIslamiyyah (Islamic fundamentalism), al-Salafiyyah (ancestral heritage), al-Sahwah al-Islamiyah (Islamic Awakening), alIhya 'al-Islami (Islamic Revival), al-Badil al-Islami (Islamic Alternative).

${ }^{17}$ al-Jâbirî, Arab-Islamic Philosophy: a Contemporary Crtitiqu, 9-11.

${ }^{18}$ Aziz Al-Azmeh, "Islamist Revivalism and Western Ideologies", History Workshop, no. 32 (Autumn, 1991), 44-53. http://www. jstor.org/stable/4289100 (accessed on April15, 2015).

${ }^{19}$ A. Luthfi Assyaukanie, "Tipologi dan Wacana Pemikiran Arab Kontemporer,” Jurnal Paramadina 1 (1998): 62-64. 
According to the principle of ideological views as written by Sayyid Qutb ${ }^{20}$, Hasan al-Banna and al-Mauduin ${ }^{21}$ which are often categorized as the central figures of this group, turāth is supported by the principle of thinking which is based on three principles; (1) Islam is a complete ideology for individuals, countries, and society, (2) al-Qur'an is the foundation for the life of Muslims in a literal sense, (3) the Sharia based on the Qur' an and al-Hadith is a 'blueprint' for Muslims. ${ }^{22}$ The study conducted by Ayyub ${ }^{23}$, Esposito $^{24}$, Mitchell25, ${ }^{25}{ }^{26}{ }^{26}$, and Roy ${ }^{27}$ shows the argumentation of this group.

In some ways, the authenticity method developed by this group is similar to the traditionalist approach, which is an approach with a model of "literal and traditional understanding of tradition" (al-fahm al-turäthi lial-Turäth). ${ }^{28} \mathrm{~A}$ common feature of this approach is its involvement in the past problems faced by tradition and surrender to it. This approach has two weaknesses: lack of critical spirit and loss of historical awareness. ${ }^{29}$

\footnotetext{
${ }^{20}$ Sayyid Qutb, Ma'alim fi al-Tariq, (Kairo: Dar al-Shauq), 9-10. ${ }^{21} \mathrm{Abu}$ al-'Ala al-Mawdudi, Towards Understanding Islam (Karachi: IIFSO, 1959), 67-69.

${ }^{22}$ Ira M. Lapidus, "Islamic Revival and Modernity: The Contemporary Movements and the Historical Paradigms", Journal of the Economic and Social History of the Orient 40, no. 4 (1997), 444460, http://www.jstor.org/stable/3632403 (accessed on January 05, 2010).

${ }^{23}$ N.M. Ayyub, "The Political Revival of Islam: The Case of Egypt", International Journal of Middle East Studies 12 (1980): 481-99.

${ }^{24}$ John L. Esposito, "Revival and Reform in Contemporary Islam", dalam, William M. Shea (ed.) The Struggle Over the Past: Fundamentalism in the Modern World (New York: University Press of America, 1993), 3-55.

${ }^{25}$ R.P. Mitchell, The Society of Muslim Brothers (London: Oxford University Press, 1969), xxiii-xxvi.

${ }^{26}$ Seyyed Vali Reza Nasr, Mawdūdī and the Making of Islamic Revivalism (Oxford: Oxford University Press, 1996), 49-68.

${ }^{27}$ Oliver Roy, The Failure of Political Islam (Cambridge, Mass.: Harvard University Press, 1994), 1-27.

${ }^{28}$ al-Jâbirî, al-Turāth wa al-Hadāthah ..., 5. This opinion is not only criticized by al-Jâbirî, but also by thinkers of his countrymen like Abdullah Laroui. He regards it as a unhistorical opinion (la tarikh).

${ }^{29}$ As a characteristic comparison, Peter Huff records six important characteristics of fundamentalism based on his observations of religious fundamentalism, especially Christianity in America. Sociologically, fundamentalism is often associated with values that are outdated or no longer relevant to changes
}

The adherents of this approach have, especially after $1967^{30}$, seen the al-Nakbah (defeatism, defeat) of the Arab-Islamic nation from Israel as a symbol of the defeat of Arab socialism. Al-Nakbah is not the defeat of the state or the Arab army but rather a symptom of the failure of Western ideological trends such as secularism, liberalism, socialism and nationalism for everything contradicts to the basic principles of Islam. ${ }^{31}$

\section{b. Transformative Approach}

If the totalistic ideal approach makes the legacy (turath) of the past as having the authority to determine the present and the future, the transformative approach is on the contrary. Those who want a transformation of turāth want liberalization by using Western tradition as a measure to define the Arab-Islamic turāth as many Orientalists do. This approach is at least similar to that developed by Orientalism. ${ }^{32}$ Figures such as Taha Husein (1889-1973) $)^{33}$ and Salamah

and developments of era; culturally, it shows a tendency to something vulgar and is not interested in intellectual matters; psychologically, it is characterized by authoritarianism, arrogance, and prone to conspiracy theories. Intellectually, it is characterized by the absence of historical awareness and inability to engage in critical thinking; and theologically, it is identified with literalism, primitivism, legalism and tribalism; whereas in politics, it is associated with reactionary populism. See, Huff, "The Challenge of Fundamentalism for Interreligious Dialogue", Cross Current (Spring-Summer, 2002), http://www.findarticles. com/cf_0/m2096/2000 (Accessed on July 8, 2015).

${ }^{30} \mathrm{Abu}$ Rabbi mentions the post-1967 fundamentalist intellectual figures such as Abd al-Qadir 'Awdah, Yusuf al-Qardhawi, Muhammad al-Ghazali, Hasan al-Turābi, Rashid al-Ghannushi, Sayyid Qutb, Muhammad Qutb, and Omar bin 'Abd Rahman. See, Ibrahim Abu Rabbi', Contemporary Arabic Thought, Studies in Post-1967 Arabic Intellectual History (London: Pluto Press, 2004), 70.

${ }^{31}$ Yoyo, "Tren Pemikiran Intelektual Muslim Kontemporer di Timur Tengah Pasca-Defitisme 1967', Kawistara 2 (2012): 225328 .

${ }^{32}$ According to Edward W. Said, orientalism theoretically involves three interrelated phenomena, (1) an orientalist is a person who teaches, writes, and examines the East, (2) orientalism is a mode of thinking based on ontological and epistemological distinction between the East and the West, (3) orientalism is discussable and analyzable. In short, orientalism is the Western way of dominating, restructuring and controlling the East. Edward W. Said, Orientalism (New York: Penthon, 1978), 6-7.

${ }^{33}$ See, Taha Husein, Mustaqbal al-Thaqafah fi Misr, III (Mesir: Dar al-Ma'arif, 1973), 54. Compare with, Syahrin Harahap, 
Musa (1887-1958) are in this group. On the other side, this approach adopts the Marxist approach, especially in its intellectual aspects as shown by Tayyib Tizini ${ }^{34}$ and Abdullah Laroui. ${ }^{35}$ These two trends, the liberal-orientalistic and the Marxist, attempt to transform the Arab-Islamic turāth into the future. Thus, the approach categorized as transformative can be observed from its liberalistic, secularistic, orientalistic, and Marxist tendencies.

In reading turāth, the liberalistic method uses Western point of view by eliminating the identity for the Arab-Islamic turäth. ${ }^{36}$ The ArabIslamic past tradition - for the sake of modernity - is considered irrelevant. ${ }^{37}$ In addition, the

Islam dan Modernitas (Jakarta: Prenadamedia, 2015), 102.

${ }^{34}$ Tayyib Tizini is mapped out by Boullata as a contemporary Arab thinker who uses the Marxist approach, especially his revolutionary theory in understanding the Arab tradition. This is clearly indicated in the title of his work under this theme, Min al-Turāth ila al-Thaurah: Hula Nazariyah al-Muqtarahah $f i$ Qadiya al-Turāth al- 'Arabi. The term "al-Thaurah" which means revolution - in Luthi Syaukani's observance - is undoubtedly a Marxist revolution. See, Tayyib Tizini, Min al-Turāth ila alThaurah: Haula Nazariyah al-Muqtarahah fi Qadiyah al-Turāth al- 'Arabi (Beirut: Dar Ibn Khaldun, 1978), 14. See also, Issa J. Boullata, 32.

${ }^{35}$ Abdullah al-Arwi, often known as Abdullah Laroui, was born in 1933 in the city of Armor. He is a Moroccan thinker and novelist who showed his concerns on turāth and modernity discourse by emphasizing on historical orientation especially on Marxist approaches in the Arab world. He received his early and secondary education at Rabat and then continued his study at the Sorbonne, Paris for political science in 1956, and obtained a postgraduate degree in 1958. He also received an honorary degree in Islamic studies in 1963. In 1976, he successfully accounted for dissertation entitled: "The Social and Cultural Basis of the Moroccan Nationality: 1830-1912" ("Moroccan National Social and Cultural Base: 1830-1912"). Cited from, http://www.arabphilosophers. com/(accessed on February 10, 2016).

${ }^{36}$ As a comparison of understanding, according to Hassan Hanafi, European consciousness penetrating the method developed by Orientalism is always motivated by dialetics between "me" and "others". This shows that the origin of European civilization is very limited both geographically and substantially. In order for Europeans to continue to exist, it is necessary to defend themselves by seeing themselves as central subjects and seeing others as colonial objects. See, Hassan Hanafi, Muqaddimah fi 'Ilm al-Istighrab (Beirut: al-Muassasah al-Jami'iyyah li alDirasat wa al Nashr wa al-Tawzi', 1992), 24.

${ }^{37}$ This group was first represented by Arab thinkers from Christian circles, such as Shibli Shumayl, Farah Antun and Salamah Musa. Now, the group is passed on by thinkers who are mostly oriented to Marxism such as Tayyib Tizini, Abdullah Laroui and Mahdi Amil, besides other liberal thinkers such as Fuad Zakariyya, Adonis, Zaki Najib Mahmud, Fair Daher and Qunstantine Zurayq. See, Issa J. Boullata, 17-22. methodological views of the Orientalists contain a pattern of confrontation with certain cultures because they read a tradition through another tradition. The philological method which is often used by Orientalists, for example, will only be able to rebuild the understanding of tradition which refers to several sources such as the Jewish, Christian, Persian, Greek, Indian, and various other sources when it is used to read tradition. ${ }^{38}$

From a methodological point of view, Orientalists generally stick to the universalism view which is based on Hegel's method of historicism. ${ }^{39}$ In addition, some hold on to the assumption of particularism with philological spirit, and others adhere to a subjectivephenomenological approach empathetic to one of the observed thinkers. ${ }^{40}$ All of them lead to Eurocentrism. The spirit of Western historicism leading to Hegel has the following principle "philosophy that has emerged lately is the result of the previous philosophical traditions, and must be related to the principles used as reference for the tradition". As the result, this historical method wholly emerges as an imperialist and hegemonic force in the history of mankind by promoting what is desired and silencing what is refused.

The Orientalist approach, for example, does not treat Islamic philosophy as a part of the cultural framework of Islam itself, but rather as a deviant and misleading continuation of Greek philosophy. The Arabic grammatical tradition (nahw) and several of its schools are also seen as a continuation of the grammatical

\footnotetext{
38al-Jâbirî, Kritik Kontemporer, 17.

${ }^{39}$ According to Hegel, historical philosophy is the history of universal thought (universal history of mankind). He is also known by his quote that all history is the history of thought. See, R.G. Collingwood, The Idea of History (London: Oxford University Press, 1956), 113-114. In Hegel's historical method, it is said that there was a thesis (positive) at first, and then the opposing power (an antithesis, negative) emerges. From here comes a synthesis (the combination of positive and negative). The Synthesis immediately becomes a new thesis, facing new antithesis and producing new synthesis. The dialectic process accordingly occurs.

${ }^{40}$ Clive Erricker, "Phenomenological Approach", in Peter Connolly, Approach to the Study of Religion (London and Yew York: Cassel, 1999), 73-104.
} 
schools of Hellenism in the city of Alexandria. Science, for example, is influenced by the logic of Aristotelianism and Islamic jurisprudence is affected by Roman law. ${ }^{41}$

The Orientalist approach which is often used by these circles is expected to have implications for the alienation of Muslims, ones of which are; first, they are alienated from their own history; second, Muslims will be alienated from their own constitution of reasoning; and third, Muslims will be alienated from their own language.

The alienation here means unconsciousness as described by Althusser. An Orientalist named Joseph Schact in An Introduction to Islamic Law once said, "Islamic law is an overview of Islamic thought, the most typical manifestation of the Muslim way of life and is the core of the essence of Islam itself'" ${ }^{42}$ From this statement, the insiders have seemed to make a sense of insecurity about their own tradition. This is the form of alienation caused by several Orientalist approaches. ${ }^{43}$

In the meantime, the Marxist approach here refers to Karl Marx (1818-1883) who is seen as one of the adherents of social tendencies in interpreting history. As a follower of the Left Neo-Hegelianism, he has exchanged the dialectics of Hegel's idealism into Dialectical materialism. In relation to Marx's historical method, it is necessary to affirm the establishment of classical Marxism as he formulated: "In the process of

\footnotetext{
${ }^{41}$ al-Jâbirî, al-Turāth wa al-Hadathah: Dirasat wa Munaqasah..., 28. To find out more about al-Jâbirî's view of Orientalism in the context of Islamic philosophy, see chapter, al-Istisghrab $f_{i}$ al-falsafah: manhaj wa al-ru'yah (Orientalisme dalam Filsafat Islam: Metodologi dan Persepsi), 63.

${ }^{42}$ Joseph Schact, Pengantar Hukum Islam, translated by Moh. Said, et.al. (Jakarta: Ditbinperta, 1985), 1.

${ }^{43}$ Although the orientalist approach has been widely criticized - even in a harsh way - by contemporary Muslim thinkers such as Muhammad 'Âbid al-Jâbirî, Hassan Hanafi, and especially Edward W. Said, does not mean denying their works which are especially considered more neutral for scientific purposes by maintaining their objectivity. The orientalists here include Reynold Nicholson, Arthur J. Arberry, John L. Esposito, Karen Armstrong, Martin Lings, Annimarie Schimmel, John O. Voll, Ira M. Lapidus, Marshal GS Hodgson, Leonard Binder, and Charles Kurtzmen. See, Karel Steenbrink, "Berdialog dengan Karya-karya Kaum Orientalis”, Journal of Ulum al-Qur'an, no. 2 (1992): 25.
}

social production for its existence, humans enter into definite and important relations which are free from their will, namely production relations in accordance with the stage of development which determines the strengths of the material production. The totality of these production relations brings up the structure of economic society, the real foundation which leads to legal and political superstructures and is related to certain forms of social awareness. ${ }^{44}$

The Marxist approach is known as the "historical materialism" method ${ }^{45}$ Such approach contains; first, from a methodological point of view, it will lead to the motivation of historical construction formulated by Hegel and based on Eurocentrism as a tool for Western imperialism. This approach is biased towards Western ideology, especially Europe. Second, from the use of this method, those who apply it to turāth do not criticize if the methodology is relevant and applicable or not. ${ }^{46}$

The Marxist approach, as mentioned above, in the context of understanding the Arab-Islamic turāth, is seen in the views of Tayyib Tizini and Abdullah Laroui. According to Tizini, for example, turāth must be in a "Historical space" and approached historically as it is history itself. He believes it is always in a dialectical relationship between the socio-economic problems and political conditions in a society. ${ }^{47}$ In this case, he proposes the theory of historical heritagial dialectics (al-Jadaliyah al-Tarikhiyyah al-Thura thiyah). ${ }^{48}$ This theory aims at creating a turāth revolution in the form of scientific socialism. In addition, it affirms the Cultural Revolution may not happen in the vacuum of social relations, as what has now happened to the Arabs.

\footnotetext{
${ }^{44}$ See Karl Marx, "Preface" and "Introduction" to A Contribution to the Critique of Political Economy (Peking: Foriegn Languages Press, 1976), 3.

${ }^{45}$ Historical materialism considers human history as a study of social class warfare. In this case, the factors of production (economic) become the driving force for war between classes.

${ }^{46}$ al-Jâbirî, Arab-Islamic Philosophy; a Contemporary Critique..., 10.

${ }^{47}$ Issa J. Boullata, 32.

${ }^{48}$ Tayyib Tizini, 254.
} 
As commonly known, the Arabs were once controlled by the feudalist bourgeoisie who could not economically stand on their own. ${ }^{49}$ They were very dependent on the Western capitalist forces, whereas the workers (read: mass) had a close emotional connection with their turāth..$^{50}$

Like Tizini, Abdullah Laroui almost has the same view. First of all, he objects the traditional approach relying the past on turäth and accordingly becoming ahistorical (la tarikh) and an eclectic modernist approach by taking on the Western elements. ${ }^{51}$ According to him, making the past as a foundation to improve the Arab social conditions is just as bad as making the West as a reference. He adds, the only solution to the rise of Arabic culture is to use Marxism as a way and means of thinking for the crisis in the Arab world. ${ }^{52}$

Besides Tizini and Laroui's view, Adonis ${ }^{53}$ deserves consideration here as a turāth thinker. Nadia Warden positions him as a Secularmodernist to distinguish him from Hassan Hanafi which she categorizes as An Islamic-modernist. ${ }^{54}$

\footnotetext{
${ }^{49}$ Here, Tizini sees class conflicts in the social reality of contemporary Arab society, between the feudalist and the bourgeois groups. For this reason, he has offered a revolutionary movement, especially the revolution of thought on their own traditions. In addition, he has openly adopted the concept of Karl Marx on the theory of class struggle. Clearly, Karl Marx said: "The history of all hitherto existing societies is the history of class struggles. Freeman and slave, patrician and plebeian, lord and serf, guild-master and journeyman, in a word, oppressor and oppressed, stood in constant opposition to one another, carried on an interrupted, now hidden, now open fight, a fight that each time ended in a revolutionary reconstruction of society at large, or in the common ruin of the contending classes." Karl Marx, The Communist Manifesto of Karl Marx and Friedrich Engels (New York: Pathfinder Press, 1970), 241.

${ }^{50} \mathrm{~A}$. Luthfi Assyaukanie, 5.

${ }^{51}$ Ibid.

${ }^{52}$ Ibrahim Abu Rabi', "Religion and Culture in the Modern Arab World: Reflections on Hisham Sharabi, (ed.) "the Next Arab Decade: Alternative Futures", Islamic Studies 28, no. 4 (1989), 403-413 http://www.jstor.org/stable/20839972 (accessed on Juni $08,2015)$.

${ }^{53}$ Adonis' real name is Aseli Ali Ahmad Said. The word Adonis was given by Anton Sa'adah, the founder and chairman of the Syrian Nationalist Party in 1940. It is taken from the name of one of the gods in the ancient Babylonian legend.

${ }^{54}$ Nadia Warden, The Problematic of Turāth in Contemporary Arab Thought: A Study of Adonis and Hasan Hanafi (Canada: The Institute of Islamic Studies McGill University, 2008), 65 and 119 .
}

Basically, Adonis' concerns on the ArabIslamic turāth are actually as big as other contemporary Islamic thinkers. During the first three centuries, the Arabic civilization chose "the old legacy" (al-Turäth al qadim) $)^{55}$, which is called al-Thabit (the established one) ${ }^{56}$ in a way that it fits the 'new' (al-Mutahawwil). In another word, his concerns as a cultural observer are a matter of Arab culture that cannot live in the present freely and calmly. The Arabic culture tends to be hostile to the present. In another word, living in modernity always tends to be anxious and hostile. This is because there is a reasoning drawn to the past.

Nevertheless, al-Thabit does not mean no change at all happens in the theoretical and praxis process throughout the history, or al-Mutahawwil does not contain elements of al-Thabits. Adonis only emphasizes the dominant and the most striking pattern in the al-Thabit tendency compared to the al-Tahawwul tendency. ${ }^{57}$

In Adonis' observation, the dialectic process al-Thabit always wins over al-Mutahawwil and it has happened since the first generation, precisely after the death of Prophet Muhammad. The case was political, about who would replace the Prophet and then shifted to the issue of

\footnotetext{
${ }^{55}$ Almost all contemporary thinkers such as Hassan Hanafi, alJâbirî, Nasr Hamid Abu Zayd, when they speak about al-Turāth al-Qadim, actually refer to products from the first to the fifth century in Hijri calendar. The tradition here is a tradition that was published and printed in the first to the fifth century in Hijri calenda, or about the seventh to the 10th century and Adonis did it. ${ }^{56}$ To fulfill the information about the terminology of al-thabit in the context of Arabic thought, Adonis refers to the idea of 'establishment' which is based on the opinion of three important thinkers who would later become reference for the next generation, (1) Ibn Ja'far Muhammad ibn Jarir at-Tabari, in his book, Tafsirat-Tabari, Jami al-Bayan, an Ta'wil ai al-Qur'an, Juz I, second edition (Cairo: Matba'ah al-Babi Al-Halabi, 1954), 35 and 54, (2) Ibn Hazm in his book, Rasail Ibn Hazm al-Andalusi, Juz IV (Ed.) Ihsan Abbas (al-Mu'assasah al-'Arabiyyah li adDirasah wal al-Nashr, 1981), 414 and (3) Ibn Taymiyyah in his book, Dar Ta'arud al- 'Aql wa al-Naql, juz I (Ed.) Muhammad Rashid Salim (Cairo: Dar al-Kutub, 1971), 191, 209, and 232. In addition, the three thinkers, Adonis specifically includes the religious thought of as-Shafi' $i$ as the foundation for the established thought by the next generation.

${ }^{57}$ Adonis, Al-Thabit wa al-Mutahwwil: Bahth fi al-Ittiba' wa alIbda' 'inda al- 'Arab, Vol. 1 (Beirut: Dar al-Saqi, 1994), 13-14.
} 
aqeedah. Since then, religion has always been a justification for political issues. Since then, the ideology of the group that dominates and controls the system (power) has been based on its unique interpretation of religion, which is strongly influenced by economic interests and political and social affiliations. ${ }^{58}$

From this historical description, the Arab society, according to Adonis, is 'imprisoned' by several characteristics which at the same time make their attitude towards the past heritage and the structure of thought typical of Arabic. He then adds four levels; first, at the existential level (theological attitude), the Arab society has an excessive tendency to separate human beings from God, and make religious concepts about God as the basis, axis, and purpose. The dominant Arabic thinking is nothing but individual, abstract, and very mythic. For this reason, the dominant civilization is a repressive civilization, a civilization of dominant system with all its institutions. Second, at the level of psychological life, the Arab society has a tendency to romanticism, the meaning is very dependent on something which is already known and denies the unknown and even worries about it. Because of the influence of this dominant cultural structure, they use the legacy of their past to understand everything and anything outside the perspective of the legacy is not worthy of any value. Third, at the level of expression and language or the separation between meaning and utterance, the Conservative Arabs prioritize rhetoric rather than writing. Fourth, at the level of the development of civilization, it contradicts to modernity. This means the Arabs who have a conservative mentality in addressing the Western modernity, on the one hand takes the results of modern civilization, but rejects the rational principle on the other. ${ }^{59}$ These characters are not their mental characteristic as a whole, but their dominant characteristics that give orientation to

\footnotetext{
${ }^{58}$ Ibid., 349.

${ }^{59}$ Ibid., xxxii.
}

their life.

From the four structures of conservative Arab thoughts due to the domination of the al-Thabit group, Adonis concludes his evaluation that the Arab life could not rise and the Arabs could not be creative if this structure of thought stays still. ${ }^{60}$

To overcome this problem, he offers a deconstruction approach to Arab culture. Basically, he agrees to deconstruct the Arabic thought, but he requires such deconstruction "from within". The attempt to deconstruct the origin must be done with the origin itself. In other words, the Arabs themselves prevent the Arabs from becoming the yesterday's Arabs. Suffice to say, the deconstructed past actually rebuilds the Arab itself.

\section{c. Reformist Approach}

According to Lutfi Asyaukani's observations, the reformist thoughts and movements ${ }^{61}$ in Islam were initially pioneered by Rifa'ah at-Tahtawi $(1801-1873)^{62}$ and at-Tunisi (1810-1889) ${ }^{63}$, and the culmination of the idea of renewal

\footnotetext{
${ }^{60}$ Ibid., xxxvi.

${ }^{61}$ The term 'reform', 'reformist', 'reformistic' which is often used in this discussion is translated from the word, islah or tajdid and commonly used in the literature of modern Islam. Meanwhile, the term tajdid is more commonly used than islah. This means renewing something which experiences incompatibility with what is supposed to be, the thing which is not in accordance with the demands of the era or its basics. Further, the term tajdid often refers to the Prophet's hadith, "Allah has sent a person who renews their (yujaddidu) religion for people at the end of a hundred years. See Sunan Abu Daud, Kitab al-Malahim, Volume 4, 109. Also see Muhammad Nurhakim, Islam, Tradisi, dan Reformasi: Pragmatisme Agama dalam Pemikiran Hasan Hanafi (Surabaya: Bayumedia, 2003), 23-24.

${ }^{62} \mathrm{Rifa}$ 'ah at-Tahtawi was the son of Egypt and al-Azhar cadre sent by the Egyptian ruler at the time, Muhammad Aly, to study in the West (France). He then tried to combine the Western methodology of thinking and culture with scientific morality and Islamic culture. Look, Nuryadin, "al-Azhar; antara Reformasi dan Konservatisme", Jurnal Taswir al-Afkar, no. 8 (2000): 59-71.

${ }^{63} \mathrm{His}$ full name is Khairuddin Pasha al-Tunisi. In the renewal thought, we can see his significant work entitled Aqwamul Masalik fi ma'rifati ahwal al-Mamalik in which he stresses the importance of achieving progress as achieved by the West. If Muslims, for example, are willing to be more advance like the Western countries, they don't need to feel guilty about adopting the Western knowledge to achieve this progress as it is not against Islam. See, A. Mukti Ali, Alam Pikiran Modern Islam di Timur Tengah (Jakarta: Djambatan, 1995), 195.
} 
was initiated by Muhammad Abduh (18651935) ${ }^{64}$ It is said the reformist movement is the evolutionary process of Muhammad Abduh's thought. However, his successors are split into two tendencies; "Left Trend" and "Right-Trend". The first tendency is reflected in the thoughts of Qasim Amin (1863-1908), Ali 'Abdul al-Raziq, (1888-1966), Muhammad Imarah (1931) and Hassan Hanafi (1935). In the meantime, the second is seen from the thoughts of Rashid Rida (1865-1935), Hasan al-Banna (1906-1949), and Sayyid Qutb (1906-1966).

If the general view of the transformational group tries to get rid of turāth for the sake of modernity and dispose of modernity in order to maintain the turāth originality as emphasized by the totalistic ideal-group. The reformist typology has a tendency to harmonize the two with a critical attitude. According to this group, prioritizing one and demeaning the other is wrong considering both are not ours, the turäth belongs to the people of the past and the modernity is owned by the West. This means, taking one and throwing the other is rash, and throwing both away is ridiculous. ${ }^{65}$ The reformist approach to turāth is divided into two trends, the trend emphasizing the reconstruction method ${ }^{66}$ of turāth and the trend underlining the deconstructive method

\footnotetext{
${ }^{64}$ The essence of this idea of reform attempts to promote the acceptance of modern Wester $n$ rationality and scientific progress claimed to be an inherent part of Islam. To discuss further studies on the idea of reform in Islam, see Mazheruddin Siddiqui, Modern Reformist Thou $\mathrm{g} h \mathrm{t}$ in the Muslim World (Islamabad: Research Institute, 1982); Charles C. Adams, Islam and Modernism in Egypt (New York: Russell \& Russell, 1968). Compare them with Tauseef Ahmad Parray, "Islamic Modernist and Reformist Thought: A Study of the Contribution of Sir Sayyid and Muhammad Iqbal", World Journal of Islamic History and Civilization 1, no. 2 (2011): 79-93.

${ }^{65}$ A. Luthfi Assyaukanie, 12.

${ }^{66}$ What it means by reconstruction here refers to Hassan Hanafi's own opinion, a reinterpretation of religious texts, an explanation of the reasons for the emergence of a tradition and its development, and an attempt to rebuild the new structure of the tradition as a whole. The redevelopment effort aims at finding general theories that have become the strengths and weaknesses of the tradition in answering the demands of the era throughout the history until now. See, Hassan Hanafi, at-Turāth wa at-Tajdid, Manqifunamin at-Turāth ..., 26.
}

over it (dismantling). ${ }^{67}$ The first approach is seen in the thoughts of Muhammad Imarah and Hassan Hanafi, while the second is reflected in the thoughts of Muhammad Arkoun and Muhammad 'Âbid al-Jâbirî.

Muhammad Imarah says the maturity of a civilization is seen in how far itis aware of the roots of the classic legacy it has. The deeper the awareness, the more resilient and mature the civilization will be. The today's Western civilization, for example, is built on the legacy of civilization and intellectual work arranged by Muslims. Muslims have adopted part of the civilization from the Greeks, while the Greeks have got it from the ancient Egyptians and Indians. This means the civilization is the work and shared property of mankind. Muslims who have brought the civilization to life from its dark hole are certainly more entitled to the today's modern civilization than any other nations. ${ }^{68}$ In his view, if the today's Muslims are willing to reconstruct their civilization by adopting the Western civilization which is currently established, then it is actually an attempt to retrieve or retake their own property. ${ }^{69} \mathrm{He}$ adds, to interact with the turäth, consensus and high awareness are needed. It is a foresight to sort out and choose the ones which are useful and exactly bring the loss from the turäth. However, the issue is which of the turäth is useful and which can actually damage. Who has the right to judge if it is beneficial and

\footnotetext{
${ }^{67}$ The meaning of deconstruction in general is the act of a subject that dismantles an object consisted of various elements worthy of dismantling. Christopher Norris, Membongkar Teori Dekonstruksi Jacques Derrida (Yogyakarta: Ar-Ruzz Media, 2008), 68 .

${ }^{68}$ Muhammad Imarah, Nazarat Jadidah Ila at-Turāth (Kairo: Dar Qutaibah, 1988), 15.

${ }^{69}$ According to Syahrin Harahap's analysis, the thinkers do not have any difference in the need for ijtihad about the idea of Islamic resurgence. But when it comes to the problem of retaking human civilization, referring to Syahrin's term, which happens in the West, there is a difference in vision which is divided into three attitudes; the most liberal attitude (Taha Hussein: 18891973), conservative attitude (al-Mauduin: 1903-1979), and synthetic attitude (Husein Haikal: 1889-1956). See Syahrin Harahap, Islam dan Modernitas: Dari Teori Modernisasi Hingga Penegakan Kesalehan Modern (Jakarta: Kencana, 2015), 101.
} 
damaging as every thinker will have different perspective? In this regard, efforts to revitalize the turāth require a big agenda and are carried out by a collective force. The separation between the useful and damaging turāth as mentioned above can only be measured and weighed from its objectives set by a big agenda. The beneficial part will eventually be disseminated to the public in general and the damaging one will be studied by experts in their field of work. ${ }^{70}$

More importantly, besides considering Muhammad Imaarah's thoughts on this trend, this study illustrates Hassan Hanafi's thoughts. According to Boullata's note, in relation to the issue of turāth, almost all of Hanafi's works lead to a large project of "legacy" studies. His book entitled al-Turāth wa al-Tajdid (Tradition and Renewal) is considered as early stages or an introduction to three following studies; (1) a number of eight volumes describe the attitudes of the Arabs who are "supposed" to "inherit"; (2) five volumes discuss the attitudes of the Arabs who are "supposed" to "inherit" the West; and (3) three volumes present the new hermeneutical theory to reconstruct human culture based on the global scale. ${ }^{71} \mathrm{He}$ defines the turāth as documentation of interpretations made by past generations in response to their needs which are limited by the corridor of their era. According to him, it is not a pile of material stored in a library or museum and free from historical reality. ${ }^{72}$ In addition, he considers the roots of contemporary thought, especially in Egypt and the Islamic world in general, can be traced from three fundamental frameworks; first, past traditions which are firmly embedded in the people who in turn contribute to shaping their thoughts and attitudes. The works

\footnotetext{
${ }^{70}$ Muhammad Imarah, 23-24.

${ }^{71}$ Issa J. Boullata, 40. Compare with, Azyumardi Azra, "Menggugat Tradisi Lama, Menggapai Modernitas: Memahami Hassan Hanafi", introductory translation in Hassan Hanafi, Dari Akidah ke Revolusi, Sikap Kita kepada Tradisi Lama (Min alAqidah ila Thaurah: al-Muqaddimat al-Nazariyah) (Jakarta: Paramadina, 2003), XVI.

${ }^{72}$ Hasan Hanafi, al-Turāth wa-al-Tajdid..., 11.
}

of classical scholars such as interpretations, jurisprudence, and the science of hadith have formed an ingrained discourse in the ummah; second, the Western tradition that has began since the Arab nations made contact with the Western world for more than four generations. This Western tradition has given rise to the modernization of Islamic thought, such as religious reform, liberalism, and secular-scientific sect; and third, the contemporary Arab reality in which Muslims interact in it both in victory or otherwise. ${ }^{73}$

To solve these three fundamental problems, Hanafi proposes three reform programs with three fundamental questions; how to deal with Islamic turāth, how to deal with Western intellectual traditions, and how to deal with contemporary reality. These three problems are drawn from Muslims' internal problems which he calls ana (self). Thus, this concept is described by the relation between ana (self) with another (akhar). The point is whether the Muslim communities behave towards the past history and the legacy it has left behind and the ways they behave towards the modern West and put it in contemporary reality at the same time. Citing Nur Hakim's opinion, these three relationships are translated as the following "hermeneutic triangles": 74

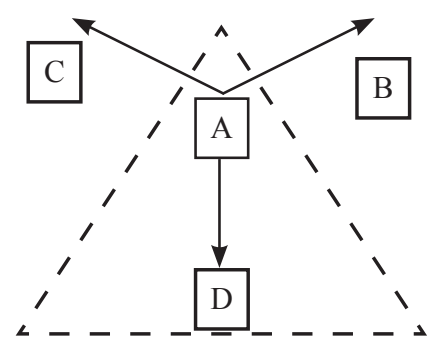

Figure 1: Hermeneutic Triangles of turāth by Hassan Hanafi

Note:
A: Ana/self (Muslim position)
B: Islamic turāth position
C: Modern Western civilization position
D: Contemporary reality position

\footnotetext{
${ }^{73}$ Ibid., 176-186.

${ }^{74}$ Mohammad Nur Hakim, Islam,Tradisi, dan Reformasi: Prgamatisme Agama dalam Pemikiran Hassan Hanafi (Surabaya: Bayumedia Publishing, 2003), 32.
} 
This relation scheme leads to an analysis that Hanafi attempts to bring three in three dimensions; past (turāth), present (modern West), and tomorrow (contemporary reality). In other words, as he said himself: "transmit the legacy and reform". ${ }^{75}$ With this way of thinking comes a question asking his position in the context of mapping his response to turāth: traditionalist, modernist, or eclecticist. ${ }^{76}$ Referring to his criticism on various schools of thought that developed at his time; traditionalist (returning to the past fully without questioning), secularist (taking the modern Western tradition totally), and modernist (taking a part of both turāth and modernity),his position does not exist in all of the three. Indeed, his idea of reformation comes from the turäth, but it has been renewed. This means he does not return literally as traditionalist. At the same time, he often uses modern Western approaches such as phenomenological and hermeneutic approaches, but his position is not the same as Muhammad Abduh or Fazlur Rahman.

Besides Muhammad Imarah and Hassan Hanafi, who are mapped out as representing the reformative circles focusing on the deconstructivereconstructive approach in this study, Muhammad Arkoun and Muhammad 'Abid al-Jabiri, two intellectuals from Morocco and al-Jazair have an almost identical intellectual tradition, their proximity to the discourse of reading texts or epistemological criticism. Both are close to the deconstructive approach. ${ }^{77}$

\footnotetext{
${ }^{75}$ Hassan Hanafi, Muqaddimat $f i$ 'Ilm al-Istghrab (Beirut: alMuassasat al-Jami'iyyah, 1992), 12.

${ }^{76}$ As commonly known, in Azyumardi Azra's note quoting Esposito and Voll's opinion, it is mentioned that Hassan Hanafi's life has arrived at the "full circle" of Islamic activists who were challenged by secular political rulers and communist opposition and attacked by conservatives. See Azyumardi Azra, "Menggugat Tradisi Lama, Menggapai Modernitas: Memahami Hasan Hanafi", introductory translation in Hasan Hanafi Dari Akidah ke Revolusi, Sikap Kita kepada Tradisi Lama ("Min alAqidah ila Thaurah: al-Muqaddimat al-Nazariyah"), ... xii.

${ }^{77}$ Ones of the goals of the deconstruction method are to show the failure of the effort to present absolute truth and to expose a hidden agenda that contains many weaknesses and inequalities behind the texts. The application of this method in dealing with the texts is: First, identifying the oppositional hierarchy
}

Arkoun discovers the most fundamental cause of the crisis in the Islamic world, the dimmed legacy of the philosophical tradition and the dogmatic understanding of Islam without critical examination which causes the development of the Islamic thought today to be frozen, closed and chaotic. In fact, according to him, Islam is not an organized religion that is rigid and dogmatic. But in its historical journey, because of power, it has become a dead dogma for the sake of power itself. For this reason, from a historical point of view, Islamic thought has become stagnated, divided, closed, narrow, and logocentric. ${ }^{78}$

He further sees the serious problems of Islamic reasoning which is controlled by logocentric with its characteristics. First, the Islamic reasonis controlled by dogmatic reasoning and closely associated with eternal truth (God) that is aesthetic instead of scientific. Second, the reasoning aimed at recognizing the truth (' $a q l$ ) has become narrow and has only focused on the area of its birthplace, for example in the fields of metaphysics, theology, morals and law. Third, the reasoning starts from general formulations and uses analogies, implications and opposition methods. Fourth, empirical data is simply used and continues to be associated with transcendental truth, and is intended as a legitimate tool for interpretation and an apology tool. Fifth, Islamic thought tends to close itself and does not see the historical, social, cultural and ethnic aspects, so it tends to be the only discourse that must be followed uniformly and taqlid (taken for granted). Sixth, the Islamic thought is more concerned with a discourse initiated in a limited space of language, according

in the texts, in which a terminology is usually systematically favored and another is not. Second, the oppositions are reversed by showing the existence of interdep e ndence between two conflicts or privately reversed. Third, a new term or idea which is apparently not included in the old oppositional category is introduced. The deconstructive reading attempts to find out the lack or failure of the text to cover itself with a single meaning or truth. F. Budi Hardiman, Filsafat Fragmentaris (Yogyakarta: Kanisius, 2007), 34-35.

${ }^{78}$ Sulhani Hermawan, "Mohammed Arkoun dan Kajian Ulang Pemikiran Islam” DINIKA 3, no. 1 (2004): 101-121. 
to the rules of the language and tends to repeat something old. In addition, inner discourses that transcend logocentric boundaries, or spiritual wealth, tend to be ignored. ${ }^{79} \mathrm{He}$ then proposed his intellectual project as a "project of criticism for Islamic reasoning" in his book, Pour Une Critique de la Raison Islamique ("Islamic Criticism"/Naqd al-'Aql al-Islami/Tarikhiyah al- Fikr al-'Arabi al-Islami).

In tracing his thoughts, it is found that Arkoun is a thinker who combines various types of developments in the discourse of science loved in France such as Derrida (Deconstruction of grammology), Lacan (psychology), Barthes (semiology), Foucault (epistemology), Saussure (linguistic), Levi strauss (anthropology), Politics (Voltaire), existentialism (Nietzche and Sartre), Rationalism (Descartes), and the socio-historical archeology of Analle school, France. This is seen from many post-structuralism concepts that he has applied in Islamic studies. The concepts such as 'corpus', 'e pisteme', 'discourse', 'deconstruction', 'myth', 'logocentrism', 'the unthinkable' and 'thought', 'parole', 'actant', etc. suffice to say, the central point of Arkoun's thought lies in this key word, epistemological criticism. ${ }^{80}$

In general, in relation to the turāth discourse, he classifies two forms of tradition. He uses two words "tradition" and turāth at the same time and distinguishes them from two types: first, "Tradition" or "Turāth" with the capital letter ' $\mathrm{T}$ ', the transcendent tradition that is always understood and perceived as the ideal tradition coming from God and cannot be changed by historical events. Such traditions are eternal and absolute. The second tradition written with a small letter ' $\mathrm{t}$ '(tradition or turāth) is shaped by history and human culture, both are inherited from

\footnotetext{
${ }^{79}$ Mohammed Arkoun, "Logocentrisme et verite religieuse dans la pensee Islamique," Studia Islamica XXXV (1972): 10-21.

${ }^{80}$ Siti Rohmah Soekarba, "Kritik Pemikiran Arab: Metode Dekonstruksi Mohammed Arkoun", Wacana 8, no. 1 (2006): 7895 .
}

generation to generation throughout the life and human interpretation of God's revelation through scriptural texts. ${ }^{81}$

The tradition in the first definition (with capital T) does not get its attention because of its transcendent nature. He only focuses on the second meaning which is considered as a text formed and standardized by history. Therefore, it must be understood according to the historical framework. Hence, the relevant approach to understanding the problem of turäth is to deconstruct it. With this approach, he aims at, among others, stopping the contradictions between two dogmatic attitudes in the form of theological truth claims from believers and ideological postulates of positivistic rationalism.

Arkoun's notes on the approach to turäth - as stated at the beginning of this discussion -attempts to read the turāth critically in space and time according to the historical journey of Muslims. The same thing is undergone by a Moroccan thinker Muhammad 'Ābid al-Jâbirî (1935-2010). The main stream of his thinking is in the epistemological and methodological problems $^{82}$ devoted throughout his intellectual career to the interests of rebuilding the ArabIslamic turāth. Therefore, the Arabic reasoning (al-'Aqlal-'Arabi) - precisely the criticism of the Arabic reasoning (Naqd al-'Aql al-'Arabi) - as an epistemic system receives considerable attention. ${ }^{83}$

\footnotetext{
${ }^{81}$ Mohammed Arkoun, Al-Fikr al-Islāmi: Qira'āt al-Ilmiyyah (Beirut: Markaz al-Inma’ al-Qaumy, 1987), 17-24.

${ }^{82}$ Epistemology derives from the Greek words 'episteme' and 'logos'. Episteme means knowledge and logos means science or theory. Epistemology is interpreted as a theory of knowledge. In English, it is often referred to as the theory of knowledge. See, Miska Muhammad Amin, Epistemologi Islam: Pengantar Filsafat Pengetahuan Islam (Jakarta: UI Press, 1983), 1. In this study, what it means by epistemology is epistemology which has been accepted, practiced and applied in the Arab-Islamic thought since the codification era until now. According to al-Jâbirî, it is divided into three: bayani, irfani, and burhani.

${ }^{83}$ To corroborate this opinion, al-Jâbirî, for example, wrote Arabic epistemological discourse in one of its trilogies specifically and seriously, Bunyah al-'Aql al-'Arabi, Dirasah Tahliliyyah Naqdiyyah li al-nzum al-ma'rifah fí at-Thaqafah al- 'Arabaiyyah. This book explores bayani, irfani, and burhani at length. Ibrahim M. Abu Rabbi' thinks al-Jâbirî's concentrationin contemporary Islamic thought is under the landscape of' methodological
} 
From here, the ways how the Arabs treat their own traditions are revealed.

Al-Jâbirî's main concern towards the turāth as the legacy from the past is that it has discovered its historical and epistemological reference framework at the time of tadwin (the period of compilation and codification of religious and linguistic sciences in the second and third century in Hijri calendar.) This Turāth was widely open for a long time until the time of its stagnation coincided with the rise of the Ottoman Empire in the tenth century in hijri calendar or the $16^{\text {th }}$ century in $\mathrm{BC}$ calendar. It is exactly the time the Renaissance in Europe grew.

The methodological mission proposed by alJâbirî is to answer the basic question on "How can we be free from the restraints of the traditional authority that binds us and how can we treat our own authority over it?" ${ }^{94}$ With such mission, he expects to treat the turāth with a rational and objective attitude. What it means by "objectivism" (maduiyah) here is making it more contextual on its own. This means it must be separated from the present context. In the meantime, what 'rationality' (ma'quliyah) means is to make it more contextual with current conditions. ${ }^{85}$ If formulated further, the methodological purpose initiated by al-Jâbirî is how to treat the turāth as something which is relevant and contextual with its own existence, especially at the level of theoretical problems, cognitive contents, and ideological substances.

\section{Conclusion}

The pattern of contemporary thinking trend in understanding turāth and modernity on the one hand, and the offered solutions to the rise of Arab-Islamic civilization on the other hand, tends to be discursive conceptual mapping. At

thinkers. See, Ibrahim M. Abu Rabbi', "The Arab world" in, Seyyed Hossein Nasr and Oliver Leaman (Ed), History of Islamic Philosophy (London and New York: Routledge), 1094.

${ }^{84}$ al-Jâbirî, at-Turāth wa al-Hadathah..., 47.

${ }^{85}$ Ibid. the same time, since 1967 - as a starting point for the second Nahdhah era - the Arab world has been hit by political conflict causing the "shaking up" in realizing the idea of resurrection. The strong tendency of fundamentalistic thoughts and movements is claimed by fundamentalists to be a sign of the resurrection itself. However, the movement has actually bought new conflicts at the same time, for the other groups.

\section{References}

Abdullah, Amin. Islamic Studies di Perguruan Tinggi, Pendekatan IntegratifInterkonektif. Yogyakarta: Pustaka Pelajar, 2006.

Adams, Charles C. Islam and Modernism in Egypt. New York: Russell \& Russell, 1968.

Ajami, Fouad. Arab Predicament: Arab Poloitical Thought and Practice Since 1967 Cambridge: Cambridge University Press, 1981.

Ali, Abd. Mukti. Alam Pikiran Modern Islam di Timur Tengah. Jakarta: Djambatan, 1995.

Amin, Miska Muhammad. Epistemologi Islam: Pengantar Filsafat Pengetahuan Islam. Jakarta: UI Press, 1983.

Arkoun, Mohammed. Al-Fikr al-Islami: Qira'āt al-Ilmiyyah. Beirut: Markaz al-Inma' alQaumy, 1987.

"Logocentrisme et verite religieuse dans la pensee Islamique." Studia Islamica XXXV (1972): 10-21.

. "Logocentrisme et verite religieuse dans la pensee Islamique." Studia Islamica XXXV (1972): 10-21.

Assyaukanie, Luthfi. "Tipologi dan Wacana Pemikiran Arab Kontemporer." Jurnal Paramadina 1 (1998). 
al-Azmeh, Aziz. "Islamist Revivalism and Western Ideologies". History Workshop, no. 32 (Autumn, 1991): 44-53. http:// www.jstor.org/stable/4289100 (accessed on April 15, 2015).

Benard, Cheryl. Civil Democratic Islam; Partners, Resources and Strategies. Rand Corporation Santa Monica: CA, 2003.

Boulata, Issa J. Trends and Issues in Contemporary Arab Thought. New York: State University of New York Press, 1990.

Bulqaziz, Abdullah. "Wahid wa 'Ishrun 'ala Hazimah Haziran: al-Asbab, al-Hasilah, al-Afaq", al-Mustaqbal al-Arabi. Juni 1998.

Collingwood, R.G. The Idea of History. London: Oxford University Prss, 1956.

Esposito, John L. "Revival and Reform in Contemporary Islam", dalam, William M. Shea (ed.) The Struggle Over the Past: Fundamentalism in the Modern World. New York: University Press of America, 1993.

Erricker, Clive. "Phenomenological Approach". In Peter Connolly. Approach to the Study of Religion. London and New York: Cassel, 1999.

Hakim, Mohammad Nur. Islam,Tradisi, dan Reformasi: Prgamatisme Agama dalam Pemikiran Hassan Hanafi. Surabaya: Bayumedia Publishing, 2003.

Hanafi, Hassan. Muqaddimah fi 'Ilm al-Istighrab. Beirut: al-Muassasah al-Jami'iyyah li alDirasat wa al Nashr wa al-Tawzi', 1992.

-------. Muqaddimat fi 'Ilm al-Istghrab. Beirut: al-Muassasat al-Jami'iyyah, 1992.

Harahap, Syahrin. Islam dan Modernitas: Dari Teori Modernisasi Hingga Penegakan Kesalehan Modern. Jakarta: Kencana, 2015.
Hardiman, Franki Budi. Filsafat Fragmentaris. Yogyakarta: Kanisius, 2007.

Hermawan, Sulhani. "Mohammed Arkoun dan Kajian Ulang Pemikiran Islam" DINIKA 3, no. 1 (2004).

Huff. "The Challenge of Fundamentalism for Interreligious Dialogue". Cross Current (Spring-Summer, 2002), http:// www.findarticles.com/cf_0/m2096/2000 (Accessed on July 8, 2015).

Husein, Taha. Mustaqbal al-Thaqafah fi Misr, III. Mesir: Dar al-Ma'arif, 1973.

Imarah, Muhammad. Nazarat Jadidah Ila atTurath. Kairo: Dar Qutaibah, 1988.

al-Jâbirî, Muhammad 'Âbid. al-Khitāb al'Arabi al-mu'asir: Dirasa tahliliyyah Naqdiyyah (Wacana Arab kontemporer: Studi analisis kritis). Beirut: Markaz Dirasat al-Wahda al-‘Arabiyyah, 1994.

-------. Fikr Ibn Khaldūn: al-'Asabiyyah wa alDawlah: Ma'alim Nadariyyah Khaldūniyyah fí al-Târikh al-Islami. Cet. 4. Beirut: Markaz Dirasat al-Wahda al'Arabiyyah, 1994.

-------. Takwin al- 'Aql al- 'Arabi. Cet. 4. Beirut: al-Markaz al-Thaqafi al-'Arabi, 1991.

------. Binyah al-'Aql al-'Arabi: Dirasah Tahliliyah Naqdiyah li nuzum al-Ma'rifah fi Thaqafah al-'Arabiyah. Cet. 3. Beirut: al-Markaz al-Thaqafi al-'Arabi, 1993.

Khalid, Detlev. "La crise des intellectuels arabes: Traditionalisme ou historicisme (The Crisis of Arab Intellectuals) by Abdallah Laroui”. Islamic Studies 14, no. 1 (1975): 77-80, http://www.jstor.org/ stable/20846938. (Accessed on February 12, 2015).

Lapidus, Ira M. "Islamic Revival and Modernity: The Contemporary Movements and the Historical Paradigms". Journal of the 
Economic and Social History of the Orient 40, no. 4 (1997): 444-460, http://www. jstor.org/stable/3632403 (accessed on January 05, 2010).

Laroui, Abdullah. The Crisis of the Arab Intellectual: Traditionalism or Historicism?. Berkeley: University of California Press, 1976.

Marx, Karl. "Preface" dan "Introduction" untuk A Contribution to the Critique of Political Economy. Peking: Foriegn Languages Press, 1976.

al-Mawdudi, Abu al-'Ala. Towards Understanding Islam, Karachi: IIFSO, 1959.

Mitchell, R.P. The Society of Muslim Brothers. London: Oxford University Press, 1969.

Nagasawa, Eiji. "An Introductory Note on Contemporary Arabic Thought", Civilisations 15, no. 1 (1965): 45-72. http:/ hdl.handle.net/100086/14819 (accessed on September 5, 2014).

Nasr, Seyyed Vali Reza. Mawdudi and the Making of Islamic Revivalism. Oxford: Oxford University Press, 1996.

Norris, Christoper. Membongkar Teori Dekonstruksi Jacques Derrida. Yogyakarta: Ar-Ruzz Media, 2008.

Nuryadin. "al-Azhar; antara Reformasi dan Konservatisme". Jurnal Taswir al-Afkar, no. 8 (2000).

Parray, Tauseef Ahmad. "Islamic Modernist and Reformist Thought: A Study of the Contribution of Sir Sayyid and Muhammad Iqbal", World Journal of Islamic History and Civilization 1, no. 2 (2011).

Putri, Feby Dasa Eka. "Krisis Minyak Tahun 1973-1974 di Negara-negara Industri sebagai Penggerak Tata Ekonomi Dunia Baru". AVATARA, Journal Pendidikan Sejarah 2, no. 1 (2014): 42-57.
Qutb, Sayyid. Ma'alim fi al-Tariq, Kairo: Dar al-Shauq, t.t.

Rabi', Ibrahim Abu. Contemprary Arab Thought, Studies in Post-1967 Arab Intelectual History. London: Pluto Press, 2004.

. "The Arab world" dalam, Seyyed Hossein Nasr and Oliver Leaman (Ed). History of Islamic Philosophy. London and New York: Routledge, 1994.

-------. 'Religion and Culture in the Modern Arab World: Reflections on Hisham Sharabi, (ed.) "the Next Arab Decade: Alternative Futures". Islamic Studies 28, no. 4 (1989): 403-413 http://www.jstor.org/stable/20839972 (accessed on Juni 08, 2015).

Roger, Louis dan Avi Shlaim (Ed). The 1967 Arab-Israel War: Origin a $n \quad d$ Consequence. Cambridge: Cambridge University Press, 2012.

Roy, Oliver. The Failure of Political Islam Cambridge. Mass.: Harvard University Press, 1994.

Said, Edward W. Orientalism. New York: Penthon, 1978.

Schact, Joseph. Pengantar Hukum Islam. Terjemahan Moh. Said, dkk. Jakarta: Ditbinperta, 1985.

Siddiqui, Mazheruddin. Modern Reformist Thought in the Muslim World. Islamabad: Research Institute, 1982.

Soekarba, Siti Rohmah. "Kritik Pemikiran Arab: Metode Dekonstruksi Mohammed Arkoun". Wacana 8, no. 1 (2006):78-95.

Steenbrink, Karel. "Berdialog dengan Karyakarya Kaum Orientalis". Jurnal Ulum al-Qur'an, no. 2 (1992).

Sutanto, Trisno S. "Islam Sebagai "Proyek": Catatan Pinggir Untuk Ulil”. Essay, dikutip dari https://www.academia.edu/7854184/ (accessed on Januari 10, 2016). 
-------. "Historisitas Pemahaman". Majalah Filsafat Diryakara XXV, no. 2.

Tizini, Tayyib. Min al-Turāth ila al-Thaurah: Haula Nazariyah al-Muqtarahah $f i$ Qadiyah al-Turāth al- 'Arabi., Beirut: Dar Ibn Khaldun, 1978.

Warden, Nadia. The Problematic of Turāth in Contemporary Arab Thought: A Study of Adonis and Hasan Hanafi. Canada: The Institute of Islamic Studies McGill University, 2008.
Yoyo. "Tren Pemikiran Intelektual Muslim Kontemporer di Timur Tengah PascaDefitisme 1967'. Kawistara 2 (2012).

Zayd, Nasr Hamid Abu. al-Nass, al-Sultah, alHaqiqah: al-Fikr al-Dini, Bain Iradah alMa'rifah wa Iradah al-Haiminat. Beirut: Markaz al-Thaqafi al'Arabi, 1994.

-------. Mafhum al-Nas: Dirasah fî 'Ulum alQur'an. Bairut: al-Markaz al-Thaqafi al-'Arabi, 1996. 